Potential production of palm oil-based foaming agent as fire extinguisher of peatlands in Indonesia: Literature review

This content has been downloaded from IOPscience. Please scroll down to see the full text. 2017 IOP Conf. Ser.: Earth Environ. Sci. 65012038

(http://iopscience.iop.org/1755-1315/65/1/012038)

View the table of contents for this issue, or go to the journal homepage for more

Download details:

IP Address: 103.10.104.75

This content was downloaded on 05/06/2017 at 07:15

Please note that terms and conditions apply.

You may also be interested in:

Palm oil based surfactant products for petroleum industry

P Permadi, R Fitria and E Hambali

Synthesis of palm oil fatty acid as foaming agent for firefighting application

M Rivai, E Hambali, A Suryani et al.

Palm oil anionic surfactants based emulsion breaker (Case study of emulsions breaker at Semanggi

Field production wells)

Muhpidah, E Hambali, A Suryani et al.

Effectiveness of Roundtable on Sustainable Palm Oil (RSPO) for reducing fires on oil palm concessions in Indonesia from 2012 to 2015

Megan E Cattau, Miriam E Marlier and Ruth DeFries

Comparison of Exponential Smoothing Methods in Forecasting Palm Oil Real Production

B Siregar, I A Butar-Butar, RF Rahmat et al.

Production of furfural from palm oil empty fruit bunches: kinetic model comparation

J R H Panjaitan, S Monica and M Gozan

Rigid palm oil-based polyurethane foam reinforced with diamine-modified montmorillonite nanoclay

Mohd Haziq Dzulkifli, Mohd Yazid Yahya and Rohah A. Majid

The Potential of Palm Oil Waste Biomass in Indonesia in 2020 and 2030

E Hambali and M Rivai 
International Conference on Biomass: Technology, Application, and Sustainable Development IOP Publishing IOP Conf. Series: Earth and Environmental Science 65 (2017) 012038

doi:10.1088/1755-1315/65/1/012038

\title{
Potential production of palm oil-based foaming agent as fire extinguisher of peatlands in Indonesia: Literature review
}

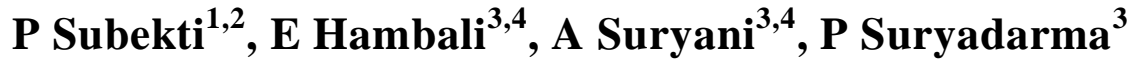 \\ ${ }^{1}$ Program Study of Mechanical Engineering, Pasir Pengaraian University, Regency of \\ Rokan Hulu, Riau, Indonesia \\ ${ }^{2}$ Post Graduate Student, Program Study Agricultural Industrial Technology, Bogor \\ Agricultural University, Bogor, Indonesia \\ ${ }^{3}$ Department of Agricultural Industrial Technology, Faculty of Agricultural Industrial \\ Technology, Bogor Agricultural University, Bogor, Indonesia \\ ${ }^{4}$ Surfactant and Bioenergy Research Center, Bogor Agricultural University, Bogor, \\ Indonesia \\ E-mail: purwos73@gmail.com
}

\begin{abstract}
This study aims to analyze the potential aplication of of palm oil-based foaming agent as peat fires fighter in Indonesia. From literature review, it has been known that the foaming agent able to form foam to extinguish fire, wrap and refrigerate the burning peat. It is necessary to develop the production and application of foaming agent in Indonesia because peat fires occur almost every year that caused smoke haze. Potential raw material for the production of environmental friendly foaming agent as foam extinguishing for peat fires in Indonesia aong other is palm oil due to abundant availability, sustainable, and foam product easily degraded in the environment of the burnt areas. Production of foaming agent as firefighting in Indonesia is one alternative to reduce the time to control the fire and smog disaster impact. Application of palm oil as a raw material for fire-fighting is contribute to increase the value added and the development of palm oil downstream industry.
\end{abstract}

\section{Introduction}

Alternative ways to accelerate peat fires fighter is using foam. In peat fires fighting, foam serves to wrap, put out the fire and cooling down the burnt area so that the fire did not initiate again. Some foaming agent has been used as fire fighter such as : Halon but but since 2000 has been banned because it produces phosgene gas which is harmful to health [1,2]; Halotron give good results but emit gases that reduce the ozone layer and in 2015, its use to be stopped [3]. As an alternative, FilmForming Fluoro Protein (FFFP) is also able to produce a good foam to extinguish the fire and more environmental friendly [4]. These materials are made overseas, so it is necessary to use local materials and abundant that are environmentally friendly in Indonesia.

Foaming agent is a foam-forming material when mixed with a certain concentration of water then stir to form foam solution. Foam is a dispersion system of gas/air in the bubbles fluid that can float on the liquid surface and flows over the surface of solids [5,6]. Pure liquid will not be foamy except surfactants that mixed in the liquid. The presence of surfactant will reduce interfacial tension of gas/liquid thus simplifying the gas dispersion in liquid to form bubbles [6,7]. Foam can be used to extinguish the fire class B such as gasoline, diesel, benzene and butane [8]. In other hand, foam can also be used to extinguish the fire class A such as material on land and forest fires [9]. 
International Conference on Biomass: Technology, Application, and Sustainable Development IOP Publishing IOP Conf. Series: Earth and Environmental Science 65 (2017) 012038

doi:10.1088/1755-1315/65/1/012038

In some countries such as the USA, Australia, Russia and Japan, the application of foaming agent from natural material to extinguish forest fire continues to develop as a substitute for synthetic materials derived from petroleum that tends to be difficult to be degraded in the environment $[9,10]$. Firefighters using foam is more quickly than water because foam wrap the burning material so that air does not enter into it. In addition, the use of foam is also make more efficient in the use of water $[4,9,10,11,12,13,14]$.

In some parts of Indonesia, forest and peat fires occurs almost every year during the dry season that resulting smoke disaster. Peat fires contribute around $85-90 \%$ of smoke disaster due to more smoke than the fire of other soil types $[15,6]$. Smoke generated from peat fires cause health problems, especially respiratory infections [15], the increase in carbon emissions, disruption of economic activity, environmental, political relations with neighboring countries and ecosystems $[17,18,19,20]$. In other hand, some activities also will be disrupted such as educational activities, transportation and health of both humans and animals.

From the description above it is necessary to study on the use of foaming agent as a material made of foam for the fire in peat lands in Indonesia as well as other countries use it, so expect smoke haze caused more quickly resolved.

\section{Research method}

This article is a review of previous research finding related to development and production of environmental friendly and sustainable fire-fighting foaming agent, using analytical description of the relevant literature and secondary data from previous researchers. Associated literatures are among others Mizuki et al. (2010) about the foaming agent environmental friendly material from fatty acids, Oguike (2013) on foam made from red palm oil, Kawahara, et al. (2016) on the development of soap based Vfire fighter agent with the basic ingredients of fatty acids, Joshua and Tickell (1999) about the potential of vegetable oil, GAPKI (2017) about the production of CPO in Indonesia and some other relevant researchers. The discusion is focused on the potential production of fire-fighting palm oil based foaming agent in Indonesia.

\section{Results dan discusion}

\subsection{Production process of foaming agent}

The production process of foaming agent firefighter with palm oil as raw material generally use palmitic, stearic and oleic acid as product from palm oil refining through etilester hydrolysis process [24]. The reaction temperature in the manufacturing process of foaming agent is between $80-95^{\circ} \mathrm{C}$, and at operating pressure of $1 \mathrm{~atm}$ [25]. Potassium chloride is also added in the reaction to reduce the viscosity of the reaction product to facilitate transportation of reaction through the pump. The neutralization reaction takes place in a circulation reactor consisting of Turbodisper and mixer. Turbodisper serves to homogenize the reactant mixture while the mixer serves to provide sufficient residence time for the reaction to react completely. Turbodisperser stirring rotation speed is between 40-50 rps and in mixer is between 5-20 rps [26]. Conversion of fatty acids reaction obtained in this way can reach more than $99.9 \%$ [25]. After the reaction occurs then the foaming agent can be directly added with additives to improve foam quality. Substances that are added to the foaming agent is include silica and acetic acid, then stir until evenly distributed [27].

To obtain firefighter foam, the foaming agent must be mixed with water in foam generator regulator. Foam will come out from regulator exhaust after the mixture of foaming agent, water and air occur. For the purpose of application on peatland, the foam should be stable, able to cover and cooling the burnt area so the fire is die and did not return. Foam stability is refers to the ability to maintain the main parameters in a constant state for a certain time. These parameters include the bubble size, fluid content, and the total volume of the foam. Foam lifetime is the simplest measure to show the stability of the foam [28]. For general application of foam as firefighter, foam is often collapse or evaporates due to pressure from the surface of the burnt areas. In addition, the main cause of foam collapse is thinning film and coalescent. Thinning occurs because the foam tends to rise to the top but also pulled 
International Conference on Biomass: Technology, Application, and Sustainable Development IOP Publishing IOP Conf. Series: Earth and Environmental Science 65 (2017) 012038

doi:10.1088/1755-1315/65/1/012038

down due to fluid flow (drainage) as a result of gravity force. Because drawn from two directions, the foam film thinned so much easier to rupture .In addition, varies foam size causes the gradient of gas pressure. As a result, the gas diffusion can occur, where small bubbles will merge into a larger foam (coalescent). The larger size of foam means the greater the surface tension, so that the foam more easily to rupture $[6,29]$.

Increasing the bulk viscosity of the fluid can prevent the foam collapse, for example with the addition of glycerol or polymers. Increasing the viscosity will reduce the drainage speed. When the drainage speed decreases, the thinning can be minimized [6]. In addition, the foam will create a steric hindrance that inhibits foam for mutually joining [29]. In addition, foam stability may also be supported by increase in the viscosity and elasticity of the surface by mixing several kinds of surfactants, in order to get a dense surfactant film and not easily to collapse[6].

\subsection{Developent of Fire Fighter foaming agent}

In some countries, land and forest fire fighting are already using more advanced technology by utilizing environmental friendly and sustainable materials. Researchers who have large contribution to develop thus material among others is Timpson LGM (1938) which developed fire fighter foam from coconut oil and palm kernel oil. The resulting foam is stable and resistant to moisture. Mizuki et al. (2007) has develop fire fighter foam for large areas using soap-based environmental friendly liquid foam with the raw material such as sodium oleic $(10 \% \mathrm{w} / \mathrm{w})$, potassium laurate $(6.87 \% \mathrm{w} / \mathrm{w})$, potassium palmitate $(0.1 \% \mathrm{w} / \mathrm{w})$, glutamatic acid diacetic acid (GLDA) $(40 \% \mathrm{w} / \mathrm{w})$ and diluents $(43.03 \% \mathrm{w} / \mathrm{w})$. The foaming agent concentration is $1 \%$ and life time of the foam is shorter than the synthesis foam. Besides as subtitute of chemicals substance that tend to damage the environment, the fire fighter foam is environmental friendly because it is easily decomposed by water and land. Mizuki et al. (2010) is also developing environmental friendly foaming agent using long chain fatty acids (LCFA), a biodegradable chelating agent and the additive that produces biodegradable foaming agent. Iwamoto et al. (2013) has developed foaming agent fire fighter from the seeds of guar gum. The foams from these materials use less water concentrations when compared to non-vegetable synthetic materials and also able to reach a wider area.

Meanwhile, Oguike (2013) has developed foaming agent fire fighter from ethyl ester of red palm oil (78.84 grams), sodium hydroxide $(68.89 \mathrm{gr})$, toluene $(125 \mathrm{ml})$ and ethanol $(50 \mathrm{ml})$ by the hydrolysis process. By ratio of foaming agent with water at 1: 8 is able to produce foam lifetime around 345 hours. The resulting foam is able to distribute uniformly cover the surface of burning liquid. Joseph et al. (2014) has developed fire fighter foam agent from potato starch, in which the test material coated with potato starch extract formulated with water is able to survive longer to burn out than uncoated test material. In 2015, Yue and Dong has developed foaming agent firefighter from rice protein, peanut and cottonseed. Foam produced from the formulation can be stored longer, low viscosity and high foam expansion power.

Likewise, Vinogradov et al. (2015) has developed the silica based foaming agent which able to extinguish fire at temperature of $800{ }^{\circ} \mathrm{C}$. The test show that the foam improve the efficiency of nearly 50 times higher than ordinary water, and 15 times better than the synthesis material. Silica can also be produced by using palm oil mill boiler ash. The ash is a combustion residue of fibers and shells of palm oil fruit, with a silica content of $86.7 \%$ in weight [34]. Kawahara et al. (2016) developed a soapbased foaming agent from chelating agent raw materials $(66.84 \% \mathrm{w} / \mathrm{w})$, potassium laurate $(4 \% \mathrm{w} /$ $\mathrm{w})$, potassium oleate $(6 \% \mathrm{w} / \mathrm{w})$, sodium oleate $(6 \% \mathrm{w} / \mathrm{w})$, methyl gliycine diacetic acid (MGDA) $(9.7 \% \mathrm{w} / \mathrm{w})$, ethylene dinitrilotetra acetic acid (EDTA) $(9.7 \% \mathrm{w} / \mathrm{w})$, nitrilotriacetic acid (NTA) $6.3 \% \mathrm{w} / \mathrm{w}$ ) and others additive. The resulting foaming agent is capable to produce a stable foam that survive at temperatures $-10{ }^{\circ} \mathrm{C}$, which has been applied for forest fire and the resulting foam is very biodegradable and environmental friendly.

Nevertheless, peat fire is differing than canopy and litter fire so that applicable foaming agent needs to pay attention on the environmental impact. Peat environmental analysis is needed to determine the extent of the effect of palm oil based foaming agent for the ecosystem after application [35,36,37,38]. 
International Conference on Biomass: Technology, Application, and Sustainable Development IOP Publishing IOP Conf. Series: Earth and Environmental Science 65 (2017) 012038 doi:10.1088/1755-1315/65/1/012038

The use of foam for forest fires fighter have increased the effect of fire fighter, surfactant in foam agent is significantly lowers the surface tension. In other hand, the use of surfactant allows more efficient water use, easy to stick on the burning material and allow water to penetrate into the combustible material. In some countries, including Indonesia, concerns about environmental damage from the use of synthetic foam cause the switch to using foam derived from natural ingredients and has extensive forest fire fighting [9]. The use of soap based foam is has much lower toxicity for aquatic organisms in rivers, lakes and the ocean compared with the synthetic foam [13,39,40,41].

Applications of peat lands firefighters in Indonesia needs to be examined to obtain foaming agents which capable form foam for firefighter, wrap, and cooling peat burning area. Fire propagation on peat land surface is around $58.1-160 \mathrm{~m}^{2} / \mathrm{min}$ with flame heights is around $1.3-2.1 \mathrm{~m}$, while fire propagation in the inner layer of peat is around 0.1-0.15 m/day [19]. With the fast fire propagation in the surface, it is required fire fighting foam that covers the surface of the burning area and can survive for some time until the fire was no longer burning. Besides the foam is resistant to hot temperatures that occur on peat fires [42].

In general, the foam used to fight the fire is easily evaporate because surface temperatures of fire is higher than foam temperature $[19,43]$ so it is required a lot of foam volume. The evaporation of the foam is caused by bubbles rupture, film layer thinning and coalescent that cause foam collapse. Thinning occurs because the foam is pulled down by fluid flow (drainage) due to gravity but once the foam tends to rise to the top. Foam film thinning is pulled from two directions, making it easier to rupture. Greater foam dimension cause greater surface tension, thus facilitating rupture $[6,28]$. By increasing viscosity of the fluid, for example with the addition of glycerol or polymers, it can prevent the foam rupture. Increasing the preparation viscosity will make drainage speed decreases, and in turn thinning can be minimized [6]. Increased surface viscosity and elasticity through mixing several kinds of surfactant to produce dense and not easily collapse surfactants film can also increase the stability of the foam [6]. In addition, it is expected that produced foaming agent is capable to increase the amount of foam and performance as well as wider range of fire fighting. Substance that are used to lower the water surface tension is surfactant that serves to increase the formation of a stable foam $[44,45,46]$, and because it is not easy to evaporate, the foam liquid is able to penetrate the surface pores of burning $[7,9]$.

\subsection{Potential production of fire fighter foaming agent}

Foaming agent is a foam material for fire fighter from vegetable fat oils and other synthetic materials. Vegetable fat oils can be used as raw material for fire fighter foaming agent $[47,48,49]$. Almost every country has potential plant-based material that can be used as raw material for the production of fatty oil. Each type of vegetable raw materials which processed into fat oil produce different yield per hectare as presented in Figure 1. 
International Conference on Biomass: Technology, Application, and Sustainable Development IOP Publishing IOP Conf. Series: Earth and Environmental Science 65 (2017) 012038 doi:10.1088/1755-1315/65/1/012038

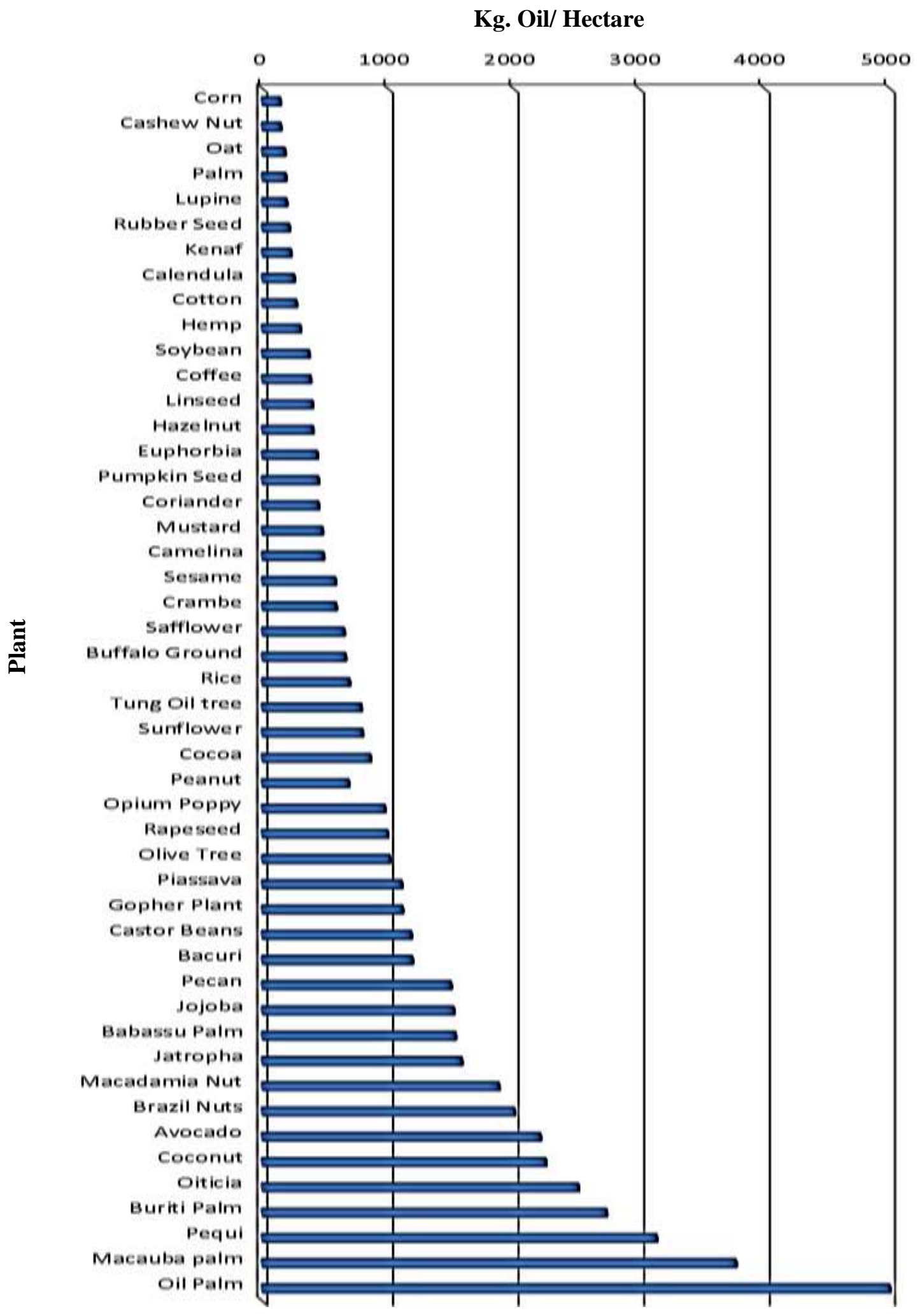

Figure 1. Oil production crops [22]

In Indonesia, there are different types of fat oil-producing plant materials that can be used as raw material for forest fighter foaming agent. Utilization of bio material as raw material for fire fighter foam is potential to be developed in Indonesia, but consideration must be paid on the potential disrupt 
International Conference on Biomass: Technology, Application, and Sustainable Development IOP Publishing IOP Conf. Series: Earth and Environmental Science 65 (2017) 012038

doi:10.1088/1755-1315/65/1/012038

of food supply. Selection of palm oil as a raw material for fire fighter foam is the right choice and the opportunity is quite large compared with other vegetable materials. In addition, the material is environmental friendly because of easily degraded and the existence will be sustainable due to abundant supply. In 2016, Indonesia produced Crude Palm Oil (CPO) and its derivative products amounted to 31.5 million tons, mostly for export (79.68\%), while the remaining for domestic consumption amounted to $20.32 \%$ [23]. Therefore, the supply of raw materials will not interfere the domestic food even will increase the added value.

Figure 1 shows that the yearly production of fatty oil is $5000 \mathrm{~kg} / \mathrm{Ha}$ from raw materials of palm fruit, the biggest oil production compared with other vegetable crops [22]. Potential production of fire fighter foaming agent need to be developed in Indonesia because forest and peat fires still continues to occur each year. Forest and peat land fires are expected to continue in line with the ongoing opening of new plantations [50]. Firefighter foaming agent will continue to be needed in Indonesia because of fires will recur from year to year, especially in the dry season, along with an increase in the number of land for plantation and drought in some forests and peat lands [51]. Raw materials of foaming agent from fatty acid of palm oil is abundant, environmental friendly and rapidly degraded to soil and water $[12,13,39,40]$.

\section{Conclusion}

Peat land firefighter with foaming agent as a medium to form foam is able to stop fire significantly. In other hand, the use of foam allows water use more efficient, easy to stick on the burning material and allow water to penetrate into the deep layers of peat land. Indonesia's concerns about environmental damage from the use of synthetic foam for the fire, causing the necessity to use foam derived from natural ingredients and with larger effects. The use of foam from fatty acid of palm oil is lower environmental toxicity on peat land than synthetic foam.

In Indonesia, the most potential material to be developed as fire fighter foam agent is fatty acid derived from palm oil and able to be produced larger than other oil sources. Palm oil is also a potential commodity that does not affect the use of food products because large part of the Indonesian palm oil is for export and only smaller percentage for domestic consumption. Production of firefighting foaming agent from palm oil is potential to be developed in Indonesia. In addition to speed up the distribution of fire fighting and minimizing smoke disaster risk, it $\mathrm{s}$ also increasing the value added of palm oil products. Peat fire fighting using foam-based soaps from palm oil allows fire fighting more quickly than water because foam blanketing burning that prevent air to enter into it.

\section{References}

[1] WMO 2007 Scientific assessment of ozone depletion: 2006 World Meteorological Organization Global (Ozone Research and Monitoring Project—Report No. 50) pp 8.15-8.32

[2] Peraturan Mentri Perindustrian RI, 2007 Tentang: Larangan memproduksi bahan perusak lapisan ozon serta memproduksi barang yang menggunakan bahan perusak ozon Permenrin RI 33 (Jakarta)

[3] Wuebbles DJ and Patten KO 2009 Three-dimensional modeling of HCFC-123 in the atmosphere: Assessing its potential environmental impacts and rationale for continued use Journal of Environmental Science \& Technology 43(9) 3208-3213 (doi:10.1021/es802308m)

[4] Krol B, Prochaska K. and Chrzanowski L 2012 Biodegradability of firefighting foams Fire technology 48 173-181 (doi: 10.1007/s10694-010-0204-7)

[5] Rosen MJ 2004 Surfactants dnd interfacial phenomena, third edition (Surfactant Research Institute Brooklyn College The City University of New York) p 277

[6] Tadros TF, 2005 Applied surfactants: Principles and applications (WILEY-VCH Verlag GmbH and Co. KgaA Weinheim) pp 155-260

[7] Schmitt TM 2001 Analysis of surfactants 2rd ed Revised and Expanded (Marcel Dekker Inc. New York) p 61

[8] Bourgeois A, Bergendahl J and Rangwala A 2015 Biodegradability of fluorinated fire-fighting foams in water Chemosphere 131 104-109 (doi.org/10.1016/j.chemosphere.2015.02.042) 
International Conference on Biomass: Technology, Application, and Sustainable Development IOP Publishing IOP Conf. Series: Earth and Environmental Science 65 (2017) 012038 doi:10.1088/1755-1315/65/1/012038

[9] Kawahara T, Hatae S, Kanyama T, Ishizaka I and Uezu K. 2016 Development of eco-frindly soapbased firefighting from for forest fire Evironmental Materials and Protocols Section: Short Communication 54(1) 75-78 (doi. 10.2525/ecb.54.75)

[10] Mizuki H, Ueza K, Kawano T, Kadono T, Kobayashi M, Hatae S, Oba Y, Iwamoto S, Mitumune S, Nagatomo Y, Owari M, Umeki H and Yamaga K. 2007 Novel environmental friendly soapbased fire-fighting agent J.Environ. Eng. Manage. 17(6) 403-408

[11] Rewet D, Smith R and Karvainis G 1996 A Comparison of water additives for mopping-up after forest fires Int. J. Wilrllarrd Fire 6(1) 37-43

[12] Oguike R S. 2013 Study of fire fighting foam agent from palm oil for extinguishing of petrol fires Material Science Research Laboratory Department of Chemistry Abubakar Tafawa Balewa University Bauchi Nigeria 1(1) 1-7 (doi:10.14340/spp.2013.12A0002)

[13] Kawano T, Otsuka K, Kadono T, Inokuchi R, Ishizaki Y, Dewancker B and Uezu K. 2014 Ecotoxicological evaluation of fire-fighting foams in small-sized aquatic and semiaquatic $\begin{array}{lllll}\text { biotopes Advanced } & \text { Materials }\end{array}$ (doi:10.4028/www.scientific.net/AMR.875-877.699)

[14] Noriyasu A, Otsuka K, Ishizaki Y, Tanaike Y, Matsuyama K, Uezu K and Kawano T 2014 A novel wild-land fire-fighting foam for minimizing the phytotoxicity of wood burning-derived smoke tested in living plant cells Advanced Materials Research. Trans Tech Publications, Switzerland 875-877 725-733 (doi:10.4028/www.scientific.net/AMR.875-877.725)

[15] Hinwood AL and Rodriguez CM 2005 Potential health impacts associated with peat smoke: A review Journal of the Royal Society of Western Australia 88 133-138

[16] Permadi DA and Oanh NTK 2013 Assessment of biomass open burning emissions in Indonesia and potential climate forcing impact Atmospheric Environment $\mathbf{7 8}$ 250-258 (doi.org/10.1016/j.atmosenv.2012.10.016)

[17] Andreae MO and Metlet P 2001 Emission of trace gases and aerosols from biomass burning Global Biogeochemical Cycles 15(4) 955-966 (doi: 10.1029/2000GB001382)

[18] Rahmayanti M 2007 Kontribusi kebakaran lahan gambut terhadap pemanasan global Kaunia 3(2) 101-117

[19] Rachmawati N 2008 Karakteristik bahan bakar dan perilaku api pada kebakaran hutan dan lahan rawa gambut Jurnal Hutan Tropis Borneo 22 55-64

[20] Toriyama T, Takahashi T, Nishimura S, Sato T, Monda Y, Awaya Y, Limin SH, Susanto AR, Darma F, Krisyoyo, Saito H and Kiyono Y 2014 Estimation of fuel mass and its loss during a forest fire in peat swamp forests of Central Kalimantan Indonesia Forest Ecology and Management 314 1-8 (doi.org/10.1016/j.foreco.2013.11.034)

[21] Mizuki H, Uezu K, Toyomura M, Yasui H, Kawano T, Akiba I, and Mizota C 2010 Microbial degradation of a shoap-based fire-fighting agent in activated sludge J. Environ. Eng. Manage 20(2) 109-113

[22] Joshua and Tickell K 1999 From the fryer to the fuel tank: The complete guide to using vegetables oils as an alternative fuel 2rd ed Tickell Energu Consulting (Tallahassee) pp 47144

[23] GAPKI 2017 Reflection palm oil industri outlook for 2016 and 2017 Indonesian palm oil association (reflection 2016)

[24] Moody CA and Jennifer AF 2000 Critical review: Perfluorinated surfactants and the environmental implications of their use in fire-fighting foams Environmental Science and Technology 34(15) 3864-3870

[25] Othmer HG 1976 The qualitative dynamics of a class of biochemical control circuits Journal of mathematical biology 3(1) 53-78

[26] Spitz dan Luis. 1996. Soap and Detergents-A Theorical and Practical Review. AOCS Press. Champaign.

[27] Vinogradov A V., Kuprin D, Abduragimov L, Kuprin G, Serebriyakov E and Vinogradov VV 2015 Silica foams for fire prevention and firefighting ACS Applied Materials \& Interfaces is published by the American Chemical Society (doi: 10.1021/acsami.5b08653)

[28] Schramm LL 2005 Emulsion, Foams and Suspensions (Wiley-VCH Verlag GmbH \& Co.KGaA, Weinheim) p 7 
International Conference on Biomass: Technology, Application, and Sustainable Development IOP Publishing IOP Conf. Series: Earth and Environmental Science 65 (2017) 012038 doi:10.1088/1755-1315/65/1/012038

[29] Exerowa D, Kruglyakov P M and Mobius R 1998 Foam and foam film: Theory, Experiment, Application (Elsevier)

[30] Timpson LGM. Patent: Pyrene Minimax Corp 1938 Method of and agent for producing fire extinguishing foam Patent United States US2135365A

[31] Iwamoto S, Ohba Y, Miki E, Mochigase H, Suzuki Y, Kurita K and Okuzaki H. Patent: Furukawa Techno Material Co., Ltd, Furukawa Electric Co. Ltd. National University Corporation University of Yamanashi 2013 Fire-extinguishing agent. Patent: Jepang WO2013141367 A

[32] Joseph P, Bakirtzis D, Richard Q. 2014 . Preliminary studies on the efficiency of an environmentally-friendly fire-fighting agent based on starch. School of the Built Environment and the Built Environment Research Institute, University of Ulster, Newtownabbey, Antrim, Northern Ireland, UK.

[33] Yue H, Dong PL, Patent: Fire Anhui Tianyuan Technology Co., Ltd. 2015 Vegetable Protein Foam Extinguishing Agent. Patent China CN104984508A Civil Aviation Organization (ICAO).

[34] Zahrina I, Yelmida and Akbar F 2012 Sintesis ZSM-5 dari fly ash sawit sebagai sumber silika dengan variasi nisbah molar Si/Al dan temperatur sintesis Jurnal Rekayasa Kimia dan Lingkungan 9(2) 94-99

[35] Utami SNH, Maas A, Radjagukguk B and Purwanto BH 2009 Sifat fisik, kimia dan FTIR spektrofotometri gambut hidrofobik Kalimantan Tengah Jurnal Tanah Trop 14(2) 159-166

[36] Tahrun M, Wawan and Amri AI 2015 The change of physical peat soil characteristics caused by fire in Teluk Binjai Village District of Teluk Meranti Regency of Pelalawan JOM FAPERTA 1(2) (Departement of Agroteknologi Faculty of Agriculture University of Riau)

[37] Vaasma T, Karu H, Kiisk M, Pensa M, Alliksaar KIT and Tkaczyk AH 2016 Pb-210 and fly ash particles in ombrotrophic peat bogs as indicators of industrial emissions Journal of Environmental Radioactivity 1-9 (doi.org/10.1016/j.jenvrad.2016.07.027)

[38] Setiawan Y, Pawitan H, Prasetyo LB, Parlindungan M, Lubis MI and Nurdiana A 2016 Characterizing spatial distribution and environments of Sumatran peat swamp area using 250 multi-temporal MODIS data (Procedia Environmental Sciences 33) (The 2nd International Symposium on LAPAN-IPB Satellite for Food Security and Environmental Monitoring LISAT-FSEM 2015) pp 117-127

[39] Lin C, Kadono T, Yoshizuka K, Uezu K and Kawano T 2006 Assessing the eco-toxicity of novel soapbased fire-fighting foam using medaka fish (Oryzias latipes, Red-orange variety) adopted to river and sea water conditions ITE Letters on Batteries, New Technologies and Medicien 7(5) 499-503

[40] Goto K, Lin C, Kadono T, Hirono M, Uezu K dan Kawano T 2007 Eco-toxicity of a soap component (sodium oleate) and a synthetic detergent cocktail using green paramecia assayed in East Asia J. Environ. Eng. Manag 17(6) 377-383

[41] Kawano T, Lin C, Kadono T dan Uezu K. 2007. Ecological risk assessment of fire-fighting chemicals using medaka fish Oryzias latipes) in different water conditions. ITE-IBA Lett. Batter. New Technol. Medic. 8: 306-311.

[42] Huang X and Rein G 2014 Smouldering combustion of peat in wildfires: Inverse modellingof the drying and the thermal and oxidative decomposition kinetics Combustion and Flame 161 1633-1644 (doi.org/10.1016/j.combustflame. 2013.12.013)

[43] Guitart NP, Rein G, Hadden RM, Belche CM and Yearsley JM 2016 Effects of spatial heterogeneity in moisture content on the horizontal spread of peat fires Science of the Total Environment (doi.org/10.1016/j.scitotenv.2016.02.145)

[44] Varade D, Carriere D, Arriaga LR, Fameau AL, Rio E, Langevin D and Drenckhan W 2011 On the origin of the stability of foams made from catanionic surfactant mixtures Soft Matter 7 6557-6570 (doi: 10.1039/c1sm05374d)

[45] Arriaga LR, Drenckhan w, Salonen S, Rodrigues JA, PalomaresRI, Rio E and Langevin D 2012 On the long-term stability of foams stabilised by mixtures of nano-particles and oppositely charged short chain surfactants Soft Matter 8 11085-11097 (doi: 10.1039/c2sm26461g) 
International Conference on Biomass: Technology, Application, and Sustainable Development $\quad$ IOP Publishing IOP Conf. Series: Earth and Environmental Science 65 (2017) $012038 \quad$ doi:10.1088/1755-1315/65/1/012038

[46] Maestro A, Rio E, Drenckhan W, Langevin D and Salonen A 2014 Foams stabilised by mixtures of nanoparticles and oppositely charged surfactants: relationship between bubble shrinkage and foam coarsening Soft Matter 10 6975-6983 (doi: 10.1039/c4sm00047a)

[47 ] Shrestha LK, Shrestha RG, Solans C and Aramaki K 2007 Effect of water on foaming properties of diglycerol fatty acid ester-oil systems Langmuir 23(13) 6918-6926

[48] Fameau AL, Ventureira J, Novales B and Douliez JP 2012 Foaming and emulsifying properties of fatty acids neutralized by tetrabutylammonium hydroxide Colloids and Surfaces A: Physicochemical and Engineering Aspects (dx.doi.org/10.1016/j.colsurfa.2012.03.059)

[49] Figueredo RCR and Sabadini E 2003 Firefighting foam stability: the effect of the drag reducer poly (ethylene) oxide Colloids and Surfaces A: Physicochem Engineering Aspects 215 77-86

[50] Anderson IP and Bowen MD 2000 Fire zones and the threat to the wetlands of Sumatra Indonesia (Forest fire prevention and control project Departemen Kehutanan kantor Wilayah Propinsi Sumatera Selatan. European Union Ministry of Forestry) p 41

[51] Adinugroho WC, Suryadiputra INN, Saharjo BH and Sibro L 2011 Manual for the Control of Fire in Peatlands and Peatland Forest (Wetlands International Indonesia Program, Indonesia) pp 2-20 